\title{
Inclusion of Vocational and Technical Education In Welfare Programmes for Prison Inmates In Nigeria. A Case Study of Nigerian Prisons in Ogun State.
}

\author{
Sonaike, Ololade Kikelomo \\ Home Economics Department, \\ School of Vocational and Technical Education, \\ Tai Solarin College of Education \\ Omu-ljebu, Ogun State \\ E-mail: ololade1012@yahoo.com \\ Phone: +2348034223625
}

\begin{abstract}
The prison is a component of the criminal justice system charged with the duty of confining, reforming, rehabilitating offenders and ensuring that on discharge they abide by the dominant values of the polity. The study focused on the inclusion of vocational and technical education as a welfare programme for inmates of prisons in Ogun State, Nigeria. Multi-stage sampling technique was employed to select respondents for the study. $50 \%$ of the prisons in the state were selected through random sampling. $10 \%$ of the inmates in the selected prisons resulted into 133 . Chi-square and Pearson Product Moment Correlation were used to analyse the results. $79.6 \%$ of the respondents were male, $75.2 \%$ in their youthful ages. $50.4 \%$ were single, $54.9 \%$ belonged to monogamous family settings while $45.1 \%$ were from polygamous homes. Respondents indicated among others the availability of good living conditions as a welfare package. Vocational education is the education that prepares people to work in a trade, a craft, as a technician or in professional vocations such as engineering, accountancy, nursing, medicine, law, architecture, catering, tailoring, agriculture, arts, computer. Vocational education can take place at the secondary, post-secondary, further education and higher education level. It can interact with the apprenticeship system. The inclusion of vocational and technical education as a welfare programme will (i) improve the welfare package available to inmates; (ii) gives inmates a chance to earn a good wage; (iii) improve their future job propects.
\end{abstract}

Keywords: prison welfare, vocational education.

Aims Research Journal Reference Format:

Matthew Chukwuma Michael \& Adigwe, M. Isioma (2018): Programmes For Prison Inmates In Nigeria. A Case Study Of Nigerian Prisons In Ogun State.. Advances in Multidisciplinary \& Scientific Research Journal. Vol. 4. No.1, Pp19-22

\section{INTRODUCTION}

The prison is a component of the criminal justice system charged institutionally for/to confine, rehabilitate offenders and ensure that on discharge they abide by the dominant values of the polity (Ayuk, Owan, and Ekok, 2013). The presence of deviants and criminals and their nefarious activities pervade every society. This has led to the formulation of a set of rules and regulations which constitute the penal policies toward the administration and dispensation of criminal justice to punish as well as reform criminally minded people. The nation's prisons harbor offenders who have committed offences ranging from stealing, armed robbery, pick pocketing, arson, murder, treason, sedition, abduction, affray, immigration offences, such as illegal smuggling of goods and persons, drug trafficking, sex, rape, traffic offences, contempt of court, unlawful possession, smuggling and attempting to escape from custody (Chimezie, 2005; Jarma, 1998; Orakwe, 1995; Womboh, 1991; Dike 2002; Fayeye, 2000). Prison reforms are attempts to improve the overall conditions of prison machines and it is aimed at a more effective penal system from one model to another essentially to improve positively the operations of the prison (Wikipedia, 2005). The purpose of prison reforms is to train through appropriate conditions convicted prisoners to be better citizens on discharge. Chimezie (2005) asserts that most inmates found in Nigerian prisons are not only youths of great strengths but of unique intelligence who are not empty-headed and lazy. 
They are in the age bracket of 18-45 which should arouse serious concerted actions by the government to include vocational education as a prison welfare program. Teaching offenders to read and write prevent them from returning to crime. Prisoners should be exposed to various vocational skills and training. The vocational courses should be designed to give them useful skills with which to make a future for themselves when they are released. Vocational and technical education according to Abdulahi (1994) is that aspect of education that involves the acquisition of techniques and application of the knowledge of science for the improvement of man's environment. Vocational and technical education is the education that prepares people for specific trades, crafts and careers at various levels from a trade, a craft, technician or a professional position in engineering, architecture, nursing, accountancy, pharmacy and catering (Wikipedia, 2010). Vocational and technical education is a planned program of courses and experiences that begin with exploration of career options, supports basic academic and life skill and enables achievement of high academic standards, leadership, preparation for industry-defined work and advanced continuing education. Vocational and technical education prepares learners for careers that are based in manual or practical activities traditionally non-academic and totally related to specific trades, occupations or vocation (Dike, 2002).

Vocational and Technical Education comprises formal, non-formal and informal learning for the world of work (UNESCO, 2012).

Philosophy of Vocational and Technical Education according to Martins (2012) include:

- To inculcate the spirit of self reliance, industry and versatility;

- To impress on the students their privileges and responsibilities as citizens of Nigeria;

- To develop, protect and project Nigerian cultured art and languages

- To equip students to live effectively in a modern age of science and technology

-

\subsection{Statement of Problem}

The inmates in Nigeria have staged impulsive protests on many occasions with some allegedly attempting jailbreak. This was attributed to inhumane treatment by the prison service as claimed by inmates. A number of inmates were reportedly shot at and many sustained varying degrees of injuries.

Furthermore, prison inmates are not engaged in any vocational skill acquisition, because most of them are awaiting trials while minorities are convicted inmates. These pose great challenge to prison institutions because vocational skills training is majorly for convicted inmates (as stated in the Prisons Standing Order 382). There is lack of adequate tools and machinery, inadequate qualified instructors in various skills, inadequate personnel like counseling psychologists, lack of personal interests on the part of prison inmates to enroll for vocational skills acquisition. These prevent adequate reformation and reintegration of prison inmates into the society. Prison reforms have been implemented. It is necessary to assess the effects of such rehabilitation program on the inmates of Nigerian prisons taking Ogun State Prison inmates as case study. It is on this background that the study assesses the possibility of including vocational and technical education in the welfare programs of prison inmates.

\subsection{Research Questions}

The following research questions guided the study:

a) What are the demographic characteristics of the inmates in Ogun State Prisons?

b) What are the welfare programs available for inmates in Ogun State Prisons?

c) Are the welfare programs accessible to the inmates?

d) What are the factors determining the provision of adequate welfare programs for inmates in the Ogun State Prisons?

e) What are the barriers to the provision of adequate welfare programmes for inmates of Ogun State Prisons?

\subsection{Research Objectives}

The broad objective of the study is to assess the inclusion of vocational and technical education in the welfare programmes for prison inmates in Nigeria taking Ogun State Prisons as a case study.

Specific objectives. The following specific objectives guided the study:

i) Identify the demographic characteristics of inmates in Ogun State Prisons

ii) Examine the accessibility of welfare programmes to the inmates of Ogun State Prisons

iii) Identify the factors determining the provision of adequate welfare programmes for inmates in Ogun State Prisons

iv) Identify the barriers to the provision of adequate welfare programmes for inmates in Ogun Sate Prisons.

\section{METHOD OF DATA COLLECTION}

\subsection{Population for the Study}

The population for the study comprised of all inmates in prisons in Ogun State. 


\subsection{Sampling Size and Sampling Technique}

Diya (2015), conducted a research on " Assessment of Welfare Programmes for Prison Inmates in Ogun State" and obtained the results that formed the data used for this research thus: Ogun State has six (6) prisons namely: Abeokuta Old Prison, Abeokuta New Prison, Ilaro Prison, Ago-Iwoye Prison, Sagamu and ljebu-Ode Prison. Fifty (50) percent of the prisons were selected using random sampling technique. The selected prisons were: Old Abeokuta Prison which was established in 1900, Ilaro and ljebu-Ode Prisons were established in 1925. Ten (10) percent of the inmates in the selected prisons were selected. This resulted into 76 inmates from Abeokuta Prison, 25 inmates from Ilaro Prison and 32 inmates from ljebu-Ode Prison. This formed the sample size for the study.

Table 1: Summary of sampling procedure

\begin{tabular}{|c|c|c|c|c|}
\hline Prisons in Ogun State & $\begin{array}{l}50 \% \text { of Prisons in } \\
\text { Ogun State }\end{array}$ & $\begin{array}{l}\text { Total number of } \\
\text { inmates }\end{array}$ & $10 \%$ of inmates & \multirow[t]{6}{*}{ Sample size } \\
\hline Old Abeokuta Prison & \multirow[t]{2}{*}{ Abeokuta Old } & \multirow[t]{2}{*}{763} & 76 & \\
\hline New Abeokuta Prison & & & & \\
\hline llaro & \multirow[t]{2}{*}{ Illaro } & \multirow[t]{2}{*}{248} & 25 & \\
\hline Sagamu & & & & \\
\hline ljebu-Ode & ljebu-Ode & & 32 & \\
\hline Ago-Iwoye & & & & 133 \\
\hline TOTAL & & 1326 & 133 & \\
\hline
\end{tabular}

Sources of Data

The data for the study were obtained from primary and secondary sources. The primary data was obtained from the responses of the inmates using a structured questionnaire. Secondary data was obtained from books, journals, publications.

\subsection{Research Design}

Descriptive survey research design was adopted for the study because it involved the collection of data about a representative sample of a population.

\section{DATA ANALYSIS}

Data collected was analyzed using descriptive statistics such as frequency counts, percentages and mean, inferential statistics like Chi-square and Pearson Product Moment Correlation.

\section{RESULTS DISCUSSION}

Socio-Economic Characteristics of Inmates in the Selected Prisons

\section{Sex of Respondents}

$79.6 \%$ of the inmates were male while $20.3 \%$ were female.

\section{Ages of Respondents}

The ages of the inmates ranged between 20 and 40 years. This implied that youths are prone to crime due to youthful energy, exuberance and little or no responsibility compared to adults. Marital Statuses of Respondents $50.4 \%$ of the respondents were single while the others were married.

\section{Educational Levels of Respondents}

$8.3 \%$ of the respondents had no formal educational. $84.2 \%$ of the inmates possessed one qualification or the other. $26.3 \%$ possessed tertiary education while $7.5 \%$ have vocational training. The implication of this is that inmates could help appropriate the rehabilitation and welfare programmes prepared for them.

\section{Number of Household Members of Respondents}

$73.7 \%$ of the respondents had less than ten (10) members in their household. The average number of members was 5 persons per household. This has implications on the relationship and the responsibilities of the inmates.

\section{Religions of Respondents}

$46.6 \%$ of the respondents were Christians while $42.1 \%$ were Muslims and $11.3 \%$ were traditional worshippers. 
Family Structure of the Respondents

$54.9 \%$ of the respondents were from monogamous families while $45.1 \%$ were from polygamous homes.

\section{Respondents' Jail term type /year of experience}

$88 \%$ of the respondents have less than twenty (20) years; $72.9 \%$ have spent less than 5 years in prison. This implied that the rehabilitations and welfare programs will help them live a normal life after the expiration of their jail terms.

\section{Welfare Packages and Rehabilitation Components Available to Respondents}

From the study, $77 \%$ of the inmates indicated that medical care was adequately available, $85 \%$ indicated enough resting time. The respondents indicated that beddings, balanced nutrition, clothing and recreational activities were not available. Other rehabilitation components and their percentages included faith based prison programmes (54.2\%), prison education programme (80.5\%), drug treatment $(65.4 \%)$, vocational skill acquisition $(61.7 \%)$, recreational activities $(88.7 \%)$ and group work programmes $(60.2 \%)$. The implication of this is that inmates have access to a wide range of rehabilitation components that aid their rehabilitation process to live a normal life.

\section{Factors Determining Rehabilitation and Provision of Adequate Welfare Packages}

According to the respondents, the following factors limited the rehabilitation and provision of adequate welfare programmes for inmates of Nigerian Prisons Ogun State: willingness to learn, poor working conditions, availability of drugs and its substance, education, capability of prison officers, health status of inmates, pressure from other inmates, lack of commitment of prison officials, poor data management, insufficient rehabilitation manpower, dearth of information, paucity of funds, corruption, lack of rehabilitation facilities.

\section{ADVANTAGES OF PROVIDING VOCATIONAL AND TECHNICAL EDUCATION TO PRISON INMATES}

What follows are the advantages of providing vocational/technical education to prison inmates

a) It provides inmates education programmes and vocational training that helps keep them from returning to prison.

b) It improves their future job prospects (Davis, 2013).

c) The training gives inmates the skills for a trade or industry.

d) The training gives inmates the chance to earn a good wage (Zoukis, 2015

\section{REFERENCES}

1. Ayuk, Awunghe A; Owan, Emeka J.; and Ekok, Omono C. (2013). The Impact of Prison Reforms on the Welfare of the Inmates: A Case Study of Afokang Prison, Calabar, Cross River State, Nigeria. Global Journal of Human Social Science, Sociology and Culture Volume 13, Issue 2, ISSN: 2249-460x and Print ISSN 0975-587X.

2. Chimezie, E. A. (2005). Penological Parliament. The reformer. 2 (1):8.

3. Dike, V.E. (2002). Prison Library Service in Nigeria. Journal of Librarianship and Information Science in Africa. 2 (1):26-37.

4. Diya, Anthony Sesan. (2015). Assessment of Welfare Programs for Prison Inmates in Ogun State. A Masters Thesis of Olabisi Onabanjo University, Ago-Iwoye, Ogun State.

5. Fayeye, O. (2000). Effectiveness of the Nigerian Prison Services for Correction and Improved Welfare for Inmates. Ph. D. Thesis, Department of Adult Education. University of Ibadan. Pg 292.

6. Jarma, I. M. (1998). The Evolution, Management and development of the Nigerian Prison Service in the Colonial and Post-Independence Era. Paper Presented at the Workshop on Management and Reform of Nigerian Prison Service, Abuja.

7. Lois M. Davis (2013). Education and Vocational Training in Prisons Reduces Recidivism, Improves Job Outlook. Retrieved onlineorg on 4th April, 2014 @ http://www.rand.org

8. Martins Chima (2012). Philosophy of Vocational and Technical Education. Retrieved Online @ http://www.Martin's library blogspot.com

9. Orakwe, I. W. (1995). The Prison and You. A Study of Diminishing Social Responsibility in Nigeria. Bulletin of ecumenical theology, violence and state security.

10. UNESCO (2012). Technical and Vocational Education and Training (TVET). Retrieved Online @ http://www.unesco.org on April 16th, 2017.

11. Wikipedia (2010). Vocational Education. Retrieved Online @ http://www.wikipedia.org on April 16th 2017. 